\title{
Psychologie der Politik
}

Eine Einführung

Ernst-August Roloff

J. B. Metzlersche Verlagsbuchhandlung Stuttgart 
CIP-Kurztitelaufnahme der Deutschen Bibliothek

Roloff , Ernst-August

Psychologie der Politik : e. Einf. -

1. Aufl. - Stuttgart : Metzler, 1976. -

ISBN 978-3-476-30052-2

ISBN 978-3-476-30052-2 ISBN 978-3-476-98800-3 (eBook)

DOI 10.1007/978-3-476-98800-3

(C) 1976 Springer-Verlag GmbH Deutschland

Ursprünglich erschienen 1976 bei J. B. Metzlersche Verlagsbuchhandlung und Carl Ernst Poeschel Verlag GmbH in Stuttgart 


\section{Inhalt}

\section{Einführung:}

Die Seele des Menschen und der Staat oder

wozu Politiker die Psychologie (miß-)brauchen

- Behaviorismus - 1

I. Die Gruppe und das Gesetz - Der »Fall Jesus « oder die Macht des Glaubens

- Hermeneutik - 21

II. Die Klasse und die Partei - der Kommunismus oder die Ideologie und das sogenannte Unbewußte - Psychoanalyse - 53

III. Die Masse und der Führer - Der Nationalsozialismus oder Macht und Grenzen der Propaganda - Feld- und Rollentheorie - 82

IV. Der Bundesbürger und seine Verfassung - Der Rechts-Staat oder »Unsere tägliche Selbsttäuschung gib uns heute « - Politische Kultur - 111

V. Trieb und Frieden oder Aggression - und kein Ende - Verhaltensforschung - 144 